\title{
Penyuluhan Hukum tentang Mahasiswa sebagai Motivator Perlindungan Konsumen di Kota Palu
}

\author{
Gunawan Arifin*1, Widyatmi Anandy², Manga Patila3, Irzha Friskanov S.4 \\ 1,2,3,4Fakultas Hukum, Universitas Tadulako, Indonesia \\ *e-mail: gunawan.arifin@untad.ac.id ${ }^{1}, \underline{\text { widyatmi@untad.ac.id }}^{2}, \underline{\text { mapator perdata@yahoo.co.id }}^{3}{ }_{2}$ \\ irzhafriskanov@untad.ac.id ${ }^{4}$
}

\begin{abstract}
Abstrak
Selama ini masih banyak masyarakat (konsumen) khususnya mahasiswa di Kota Palu yang belum mengetahui tentang regulasi yang mengatur dan melindungi hak-hak mereka sebagai konsumen. Oleh karena itu, perlu adanya pengetahuan dan pemahaman untuk mengatasi permasalahan tersebut, agar kedepannya masyarakat terhadap hukum semakin baik, dan pada akhirnya dapat meminimalisir tindakan pelaku usaha yang dapat merugikan konsumen. Pengabdian ini laksanakan yang menghadorkan mahasiswa yang tergabung dalam Ikatan Pemuda Pelajar Mahasiswa Kabupaten Luwu Timur (IPPMK-Lutim). Dengan metode yang dilakukan yakni metode ceramah dan diskusi dengan mahasiswa yang hadir. Hubungan hukum dalam perlindungan konsumen merupakan hubungan hukum segitiga dengan menempatkan konsumen dan pelaku usaha sebagai pelaku utama dalam proses transaksi barang dan/atau jasa. Hubungan ini dalam ranah hukum privat dimana kedua belah pihak memiliki kedudukan yang setara. Hubungan hukum terjadi berdasarkan asas kebebasan berkontrak dan asas konsensualitas. Selain konsumen dan pelaku usaha, terdapat pihak ketiga yaitu pemerintah yang berperan sebagai regulator dalam mengatur pola hubungan hukum antara konsumen dengan pelaku usaha. Oleh karena itu, mahasiswa dipelolopri sebagai motivator yang diharapkan akan dapat lebih paham dalam regulasi perlinddungan konsumen terlebih dalam kondisi pandemi ini.
\end{abstract}

Kata Kunci: Konsumen, Mahasiswa, Pandemi

So far, there are still many people (consumers) especially students in Palu who do not know about the regulations that regulate and protect their rights as consumers. Therefore, it is necessary to have knowledge and understanding to overcome these problems, so that in the future the community will be better at law, and in the end can minimize the actions of business actors that can harm consumers. This service is carried out by presenting students who are members of the East Luwu Student Youth Association (IPPKLutim). The method used is the lecture method and discussion with the students present. legal relationship in consumer protection is a triangular legal relationship by placing consumers and business actors as the main actors in the transaction process of goods and/or services. This relationship is in the realm of private law where both parties have an equal position. Legal relations occur based on the principle of freedom of contract and the principle of consensuality. In addition to consumers and business actors, there is a third party, namely the government which acts as a regulator in regulating the pattern of legal relations between consumers and business actors. Therefore, students are pioneered as motivators who are expected to be able to understand more deeply about consumer protection regulations first in this pandemic condition.

Keywords: Consumers, Pandemic, Students

\section{PENDAHULUAN}

Hubungan hukum dalam perlindungan konsumen merupakan hubungan hukum bersegi tiga dengan menempatkan konsumen dan pelaku usaha sebagai pelaku utama dalam proses transaksi barang dan/atau jasa. Hubungan ini berada dalam ranah hukum privat dimana kedua belah pihak memiliki kedudukan yang setara. Hubungan hukum terjadi dilandaskan asas kebebasan berkontrak dan asas konsensualitas. Selain pihak konsumen dan pelaku usaha, terdapat pihak ketiga yakni pemerintah yang bertindak sebagai regulator dalam mengatur pola hubungan hukum antara konsumen dan pelaku usaha. Olehnya, kedudukan pemerintah bersifat sub-ordinat terhadap konsumen dan pelaku usaha. Eksistensi sebagai regulator tunduk pada 
hukum publik, sehingga dapat memaksakan kehendaknya kepada para pihak demi mewujudkan kesejahteraan umum.

Hasil Penelitian Tahun 2020 di Provinsi Sulawesi Tengah yang dilaksanakan oleh Asri Lasatu, Sahrul, dan Insarullah menujukkan hasil bahwa dari 498 responden yang mengisi kuisioner terdapat 172 responden $(34,5 \%)$ yang belum mengetahui adanya Undang-Undang Nomor 8 Tahun 1999 tentang Perlindungan Konsumen (Asri Lasatu \& dkk, 2020). Angka ini tergolong tinggi jika dibandingkan dengan umur undang-undang tersebut yang memasuki usia ke 21 Tahun. Fakta ini dapat dimaknai bahwa masyarakat (konsumen) Provinsi Sulawesi Tengah selama ini masih banyak yang belum mengetahui adanya regulasi yang mengatur dan melindungi hak-haknya sebagai konsumen. Olehnya, perlu upaya kongkrit dari pemerintah daerah, dan pihak-pihak terkait termasuk perguruan tinggi untuk mengatasi masalah tersebut, sehingga ke depan pengetahuan dan pemahaman masyarakat terhadap undang-undang tersebut lebih baik, dan pada akhirnya dapat meminimalisir tindakan-tindakan pelaku usaha yang dapat merugikan konsumen.

Salah satu pertimbangan pembentukan undang-undang a quo adalah untuk meningkatkan harkat dan martabat konsumen perlu meningkatkan kesadaran, pengetahuan, kepedulian, kemampuan dan kemandirian konsumen untuk melindungi dirinya serta menumbuhkembangkan sikap pelaku usaha yang bertanggung jawab (Konsideran menimbang huruf d UU No. 8 Tahun 1999 tentang Perlindungan Konsumen). Sedangkan tujuan pembentukan undang-undang a quo dalam Pasal 3 Undang-Undang Nomor 8 Tahun 1999 tentang Perlindungan Konsumen adalah:

a. meningkatkan kesadaran, kemampuan dan kemandirian konsumen untuk melindungi diri;

b. mengangkat harkat dan martabat konsumen dengan cara menghindarkannya dari ekses negatif pemakaian barang dan/atau jasa;

c. meningkatkan pemberdayaan konsumen dalam memilih, menentukan dan menuntut hakhaknya sebagai konsumen;

d. menciptakan sistem perlindungan konsumen yang mengandung unsur kepastian hukum dan keterbukaan informasi serta akses untuk mendapatkan informasi;

e. menumbuhkan kesadaran pelaku usaha mengenai pentingnya perlindungan konsumen sehingga tumbuh sikap yang jujur dan bertanggung jawab dalam berusaha;

f. meningkatkan kualitas barang dan/atau jasa yang menjamin kelangsungan usaha produksi barang dan/atau jasa, kesehatan, kenyamanan, keamanan, dan keselamatan konsumen.

Mahasiswa merupakan kaum intelektual yang dapat berpengaruh dalam pengetahuan di masyarakat, apalagi masyarakat belum memahami tentang regulasi perlindungan konsumen. Bukan hanya itu, konsumen dalam perannya masih pasif daripada produsen yang sifatnya aktif. Bahkan tipikal konsumen yang "masa bodo" dan kurang peduli, padahal konsumen telah memiliki hak-haknya yang diatur dalam regulasi perlindungan konsumen. Konsumen bukan hanya masyarakat yang membeli suatu barang tetapi produsen pula termasuk konsumen. Dengan meningkatnya jenis produk yang menjadi konsumsi masyarakat, tidak didukung dengan sosialisasi yang memadai. Maka konsumen tidak memahami apa saja yang menjadi regulasi perlindungan baik hak dan kewajibannya. Bukan hanya hak, tetapi konsumen juga harus ikut berperan dalam pengawasan.

Mahasiswa sebagai motivator merupakan penggerak atau seseorang yang mendorong perubahan yang terjadi untuk melakukan suatu tindakan yang menjadikan kebutuhan atau tujuan. Kesiapan mahasiswa yang mendapat materi dalam penyuluhan inilah yang menjadi sasaran untuk dalam menerima pengetahun dan pemahaman tentang perlindungan konsumen.

Atas pertimbangan tersebut, pengabdi akan melakukan kegiatan dalam bentuk ceramah, simulasi dan diskusi tentang perlindungan konsumen dengan target memberikan motivasi kepada sasaran (mahasiswa) agar menjadi motivator perlindungan konsumen dalam masyarakat. Berdasarkan analisis situasi di atas, permasalahannya adalah apa upaya yang harus dilakukan dalam rangka meningkatkan pengetahuan dan pemahaman masyarakat tentang perlindungan konsumen. 


\section{METODE}

Metode pengabdian yang digunakan dalam penyuluhan hukum ini adalah dengan menggunakan metode materi, simulasi dan participatory rural appraisal (PRA), karena dengan menggunakan teknik demikian dapat mengetahui tingkat pemahaman mahasiswa yang tergabung dalam Ikatan Pemuda Pelajar Mahasiswa Kabupaten Luwu Timur.

Adapun metode yang akan digunakan dalam kegiatan ini adalah sebagai berikut, Pertama, metode ceramah; metode ini diberikan dalam penyampaian materi pokok yang bersifat teoritis, di mana materi dibawakan oleh beberapa orang sebagai pemateri, yang kemudian dilanjutkan dengan sesi tanya jawab dengan para siswa. Kedua, dynamic group; metode ini dilakukan dengan membagi peserta dalam bentuk kelompok di mana setiap kelompok akan berdiskusi dengan dipandu oleh seseorang kemudian diberikan tugas untuk dikerjakannya. Lokasi pengabdian akan dilaksanakan di Kota Palu dengan sasaran utama adalah mahasiswa yang berdomisili di Kota Palu, baik yang tergabung dalam organisasi Ikatan Pemuda Pelajar Mahasiswa Kabupaten Luwu Timur (IPPMK-LUTIM) maupun mahasiswa lainnya.

Model pengabdian yang diterapkan adalah ceramah, konsultasi dan simulasi. Evaluasi dilakukan untuk menilai tingkat keberhasilan dari kegiatan pelatihan kepada sasaran yakni mahasiswa yang berdomisili di Kota Palu. Aspek yang dinilai dari kegiatan pengabdian ini mencakup keterlibatan dan pemahaman mahasiswa terhadap pentingnya Motivator Perlindungan Konsumen.

\section{HASIL DAN PEMBAHASAN}

Tujuan pembentukan Negara Indonesia adalah melindungi dan menyejahterakan seluruh rakyat. Olehnya, negara terutama pemerintah bertanggungjawab atas pemenuhan hak konstitusional (Oki Wahju Budijanto, 2017) setiap warga negara untuk mendapatkan perlindungan dan kepastian hukum yang adil sebagai amanat Pasal 28D ayat (1) UUD NRI 1945. Perlindungan hukum merupakan manifestasi negara hukum Indonesia yang dalam catatan sejarah meliputi serangkaian catatan kejadian penting dan jejak peristiwa mengenai hukum yang berlaku di masa lalu sebagai bagian yang tidak terpisahkan dengan perjalanan hukum Indonesia hingga saat ini. Sejarah hukum Indonesia membentang jauh sebelum Proklamasi kemerdekaan (Irwansyah, 2020). Setiap sistem hukum memiliki ciri menonjol dan karakteristik yang berbeda satu dengan yang lainnya. Perbedaan sistem hukum berimplikasi positif pada tersedianya alternatif untuk penguatan sistem hukum yang dipraktikkan dan dikembangkan disetiap negara (Irwansyah, 2020).

Perlindungan hukum merupakan konsep universal yang berlaku pada semua negara yang menganut paham atau kedaulatan hukum. Olehnya, tidak berlebihan jika konsep tersebut banyak di kaji dan dikembangkan oleh ahli hukum, negarawan, termasuk pemerhati politik dan demokrasi. F.H. van der Burg, dalam bukunya Rechtbescherming tegen de Overheid, sebagaimana dikutip oleh Philipus M. Hadjon membagi dua perlindungan hukum bagi rakyat yaitu perlindungan hukum yang preventif dan perlindungan hukum yang bersifat represif. Perlindungan hukum preventif mencegah terjadinya sengketa sedangkan perlindungan hukum represif bertujuan untuk menyelesaikan sengketa (Philipus M. Hadjon, 2007).

Mahasiswa yang menjadi sasaran dari penyuluhan hukum ini yakni untuk dapat mendapat pengetahuan untuk memberikan penerangan dan motivasi kepada orang lain terkait perlindungan konsumen, baik melalui seminar maupun pelatihan. Dengan menjadi sebagai motivator, mahasiswa mendapatkan output sebagai pribadi yang jujur dan bijak dalam memberikan informasi terkait konsumen. Sebagai konsumen, wajib membaca atau mengikuti petunjuk informasi dan prosedur pemakaian atau pemanfaatan barang dan/atau jasa, demi keamanan dan keselamatan.

Perlindungan konsumen dilaksanakan berasaskan manfaat, keadilan, keseimbangan, keamanan dan keselamatan konsumen, serta kepastian hukum. Tujuannya, antara lain meningkatkan kesadaran, kemampuan dan kemandirian konsumen untuk melindungi diri, 
mengangkat harkat dan martabat, menumbuhkan kesadaran pelaku usaha mengenai pentingnya perlindungan konsumen, serta meningkatkan kualitas barang dan/atau jasa.

Perlindungan hukum merupakan konsep universal yang berlaku pada semua negara yang menganut paham atau kedaulatan hukum. Olehnya, tidak berlebihan jika konsep tersebut banyak di kaji dan dikembangkan oleh ahli hukum, negarawan, termasuk pemerhati politik dan demokrasi. F.H. van der Burg, dalam bukunya Rechtbescherming tegen de Overheid, sebagaimana dikutip oleh Philipus M. Hadjon membagi dua perlindungan hukum bagi rakyat yaitu perlindungan hukum yang preventif dan perlindungan hukum yang bersifat represif. Perlindungan hukum preventif mencegah terjadinya sengketa sedangkan perlindungan hukum represif bertujuan untuk menyelesaikan sengketa (Philipus M. Hadjon, 2007).

Perlindungan hukum secara preventif dilakukan untuk mencegah agar kejahatan/pelanggaran atau sengketa itu tidak terjadi. Hal tersebut dapat dilakukan dengan cara moralistik dan dan cara obolionistik. Moralistik adalah meningkatkan kekuatan mental dan moral masyarakat agar tidak mudah melakukan tindak kekerasan (pelanggaran hukum). Sedangkan cara obolionistik yaitu mencegah atau mengurangi faktor-faktor penyebab timbulnya pelanggaran hukum agar tidak terulang lagi (Yudhi Setiawan, 2017). Cara moralistik dalam kaitannya dengan perlindungan konsumen berarti upaya-upaya yang dapat meningkatkan pemahaman pelaku usaha dan konsumen terhadap hak dan kewajiban masing-masing pihak agar tidak terjadi tindakan-tindakan yang dapat merugikan pihak lain. Kegiatan ini dapat dilakukan melalui sosialisasi, penyuluhan, pembinaan agama, pembinaan etika dan lain-lain.

Berikut dokumentasi kegiatan penyuluhan terbatas yang dilaksanakan bersama mahasiswa dikarenakan kondisi pandemi yang meningkat di Kota Palu.

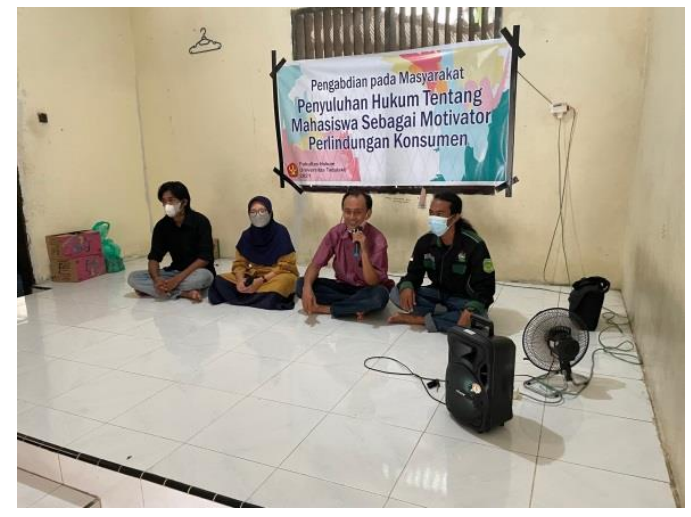

Gambar 1. Pemateri dan mitra perwakilan mahasiswa pada kegiatan

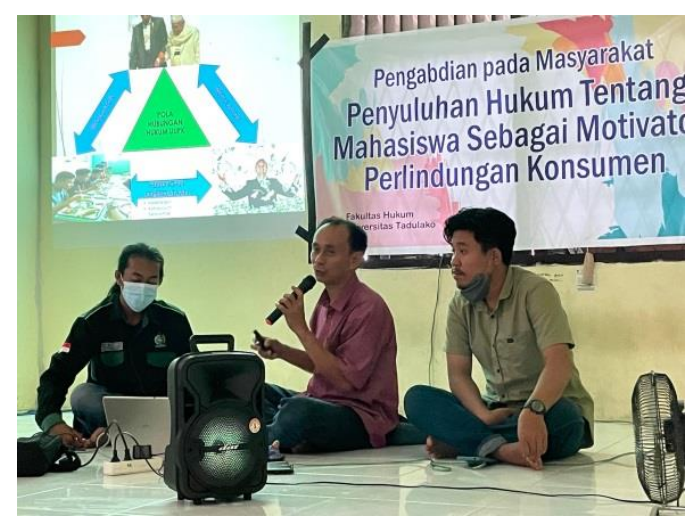

Gambar 2. Pemateri menjelaskan poin-poin penting kepada peserta

Materi penyuluhan ini bertujuan untuk memberikan penerangan dan motivasi untuk mahasiswa agar menjadi motivator dalam pengetahuan regulasi perlindungan konsumen. Mahasiswa yang mendapatkan materi kegiatan ini diharapkan dapat memberikan dorongan kepada orang lain dalam memahami hak dan kewajiban konsumen. Kemudian meningkatkan 
produktivitas kerja serta menciptakan hubungan kondusif sebagai pelaku konsumen maupun pelaku usaha. Sebagai konsumen, pada Undang-Undang Nomor 8 Tahun 1999 tentang Perlindungan Konsumen dijelaskan tentang pemenuhan hak dalam Pasal 4 dan pelaksanaan kewajiban dalam Pasal 5. Kemudian pada pelaku usaha dijelaskan tentang pemenuhan hak dalam Pasal 6 dan pelaksanaan kewajiban dalam Pasal 7. Serta pada pemerintah dijelaskan dalam pembentukan regulasi dan mewujudkan tujuan UUPK pada Pasal 3.

Kegiatan ini diharapkan output kemitraan antara konsumen, pelaku usaha dan pemerintah yakni jujur, bijak, kritis, dan adil sebagai wujud tujuan Negara Kesatuan Republik Indonesia.

\section{KESIMPULAN}

Berdasarkan uraian, maka dapat disimpulkan bahwa mahasiswa minim pengetahuan dalam perlindungan konsumen baik apa yang digunakan maupun pembagian macam-macam konsumen kemudian dipengaruhi oleh faktor budaya masyarakat. Faktor tersebut diperparah dengan adanya bencana sosial pandemi COVID-19 yang menyebabkan mobilitas masyarakat terbatas. Dengan adanya penyuluhan hukum ini, diharapkan mahasiswa mampu memberikan dorongan sebagai motivator untuk memberikan informasi terkait perlindungan konsumen baik untuk diri sendiri maupun untuk orang lain. Dalam kegiatan ini, mahasiswa mampu menjadi pendorong atau motivator dalam memahami pemenuhan hak dan pelaksanakan kewajiban serta regulasi perlindungan hukum. Dan mahasiswa mampu memahami pelaku usaha dan pemerintah dalam pemenuhan hak dan pelaksanaan kewajiban.

\section{UCAPAN TERIMA KASIH}

Banyak pihak yang telah memberikan bantuannya sehingga tulisan ini dapat terlaksana dan selesai, yang tidak mungkin dituliskan satu per satu. Kepada mereka, penulis haturkan terima kasih yang sebesar-besarnya. Secara khusus penulis ucapkan terima kasih pada Fakultas Hukum Universitas Tadulako dan mahasiswa yang telah membantu agar kegiatan pengabdian ini dapat terlaksanakan dan terselesaikan.

\section{DAFTAR PUSTAKA}

Asri Lasatu dkk, (2020), Badan Penyelesaian Sengketa Konsumen sebagai Sarana Perlindungan Hukum Rakyat, Laporan Penelitian Unggulan Perguruan Tinggi, Fakultas Hukum Universitas Tadulako.

Irwansyah, (2020), Refleksi Hukum Indonesia, Mirra Buana Media, Yogyakarta. , Kajian Ilmu Hukum, Mirra Buana Media, Yogyakarta, 2020.

Oki Wahju Budijanto, (2017), "Peningkatan Akses Bantuan Hukum Kepada Masyarakat Miskin," Jurnal Penelitian Hukum De Jure 16, Nomor 4.

Philipus M. Hadjon, (2007), Perlindungan Hukum Bagi Rakyat di Indonesia (edisi khusus), Peradaban, 2007.

Undang-Undang Nomor 8 Tahun 1999 Tentang Perlindungan Hukum (Lembaran Negara Republik Indonesia Tahun 1999 Nomor 42; Tambahan Lembaran Negara Republik Indonesia Nomor 3821).

Yudhi Setiawan, dkk, (2017), Hukum Administrasi Pemerintahan, Teori dan Praktik, Rajagrafindo Persada, Jakarta, 2017. 


\section{Halaman Ini Dikosongkan}

